\title{
worldview
}

A JOURNAL OF RELIGION AND INTERNATIONAL AFFAIRS

\section{THE COMMUNIST BLOCS AND THE TREATY}

The cold war has been complicated and partially reshaped by two dramatic events within the last few weeks. The first is the direct confrontation of the opposing opinions and interests of the Soviet Union and Communist China. The second, is the test-ban treaty initialled in Mos. cow by the Soviet Union, Britain and the United States.

Neither of these events brings the cold war to a halt or dissolves long-standing alliances. But each reveals some of the complexities that many cold war analysts have overlooked or chose to ignore. Even as the differences between China and the Soviet Union were becoming more evident and there was undeniable evidence that Russian trade and aid was being withdrawn from China, there were many commentators who dismissed the differences as inevitable and negligible. Communist ideology, they insisted, was a binding substance of great strength that could and would hold together nations of different and even opposing interests. At least as long as Russia was the economic and military giant among the nations of the Communist bloc it would be, they maintained, the ruling center of the Communist world. The declared differences between Russia and China have put this dictum to a test that it is not long likely to survive, for the differences were stated precisely in terms of ideology.

What is almost immediately obvious is that the interpretations of the Marxist-Leninist ideology put forth by China and Russia corresponded rather neatly to the conditions of the two countries. Russia, with more to lose, and with more knowledge of the great destruction nuclear weapons can visit upon any country, was correspondingly more fearful and more responsible. On various questions intimately involved with questions of war and peace, the Chinese spokesmen were consistently more rigid and aggressive. What many people had advanced spec- ulatively was shown to be true: China had been urging Russia to take a tougher line at the time of the Cuban blockade, even to the extent of risking a nuclear war.

A quarrel between Communist allies does not automatically make either one a friend of the West. But the consequences of the division between Russia and China may have far-reaching consequences both within the Communist bloc and without. Time, in this case, is on the side of the West.

The test-ban treaty is, of course, of at least equal significance. Here, too, one's hopes and expectations must be tentative. But the disappointments and misplaced confidences of the past must not lead to a foolish and paralyzing pessimism now. There are two major points to grasp about the treaty: first, it is an extremely narrow, limited agreement; second, an agreement, even as limited as this, is an important achievernent which may give rise to broader and more important agreements.

President Kennedy stressed the limiting aspects of the treaty in his report to the nation. "This treaty is not the millenium. It will not resolve all conflicts, or cause the Communists to forego their ambitions, or eliminate the dangers of war. It will not reduce our need for amns or allies or programs of assistance to others. But it is an important first step-a step toward peace -a step toward reason-a step away from war."

The question before this country now is whether the treaty should be ratified. There are a number of sometime Cassandras who can be counted on to oppose the ratification, a number of people whose distrust of the Commumists prevents them from seeing that some measures may be beneficial to both the Western nations and the Soviet Union. Yet, as Walter Lippmann pointed out, if the Senate does not ratify this 
treaty, the United States will be rejecting a treaty similar to one which it has been proposing for almost a year. He also pointed out with compelling logic that the major objection to the treaty comes from those who wish to continue the arms race in search of the great, final, weapon which will swing the balance of power decisively in one direction.

The issue is grave and immediate and deserves the great public debate President Kennedy called for. If ratified, the treaty will represent the first positive measure to control the unintended harmful effects of nuclear testing, effects from which no person is wholly immune. If ratified, it may lead to other measures which will further ensure the continued uneasy conditions we now endure and, possibly, even improve them. If not ratified, there will be little hope that there will soon be another opportunity to limit the arms race and look forward to any meaningful arms control.
There are many interdependent reasons for ratifying the treaty. But they have differing priorities, they should be seen within an overall, consistent framework of our gencral political purposes. Although the article by Paul Ramsey which appears in this issue of worldview was written before the present treaty was initialled in Moscow it provides a framework within which the ratification of the treaty may well be discussed and debated.

Beyond the issue of the treaty and the SinoSoviet conflict is the relation between the two. The present constellations of power within the Communist bloc will change only under great pressures. It will be to the benefit of all the Western nations-including France-if the leading Western nation can properly judge whether the variety of "peaceful coexistence" proposed by Khrushchev is more productive than the more militaristic policies of China. The test ban treaty may well test more than the treaty.

\section{President Kennedy on the Test Ban Treaty}

"... this limited treaty will radieally reduce the nuclear testing which would otherwise be conducted on both sides; it will prohibit the Cnited States, the United Kingdom, the Soriet Union and all others who sign it from engaging in the atmospheric tests which have so alarmed mankind: and it offers to all the world a welcome sign of hope."

"No one can predict with certairty, therefore, what future agrement, if any, can be built on the foundations of this one... But the diffculty of predicting the next step is no reason to be relictant about this one. Nuclear test ban negotiations have long been a symbol of FastVest disagreement. If this treaty can also be a symbol-if it can symbolize the end of one era and the beginning of another-if both sides can by this treaty gain confidence and experience in peaceful collaboration-then this short and simple treaty may well become an historic nurk in man's age-old pursuit of peace."

"This limited test ban in our most careful judgment is safer by far for the United States than an unlimited nuclear arms race. For all these reasons $I$ am hopeful that this nation will promptly approve the limited test ban treaty. There will, of course, be debate in the country and in the Senate. The Constitution wisely requires the advice and consent of tho Senate to all treaties, and that consultation has already begun.

${ }^{4}$ All this is as it should be. A document which may mark an historic and constructive opportunity for the world deserves an historic and constructive debate. It is my hope that all of you will take part in that debate, for this treaty is for all of us.

"It is particularly for our children and our grandeluldren, and they have no lobby here in Washington.

"This debate will involve military, scientific and political experts. But it must be not left to them alone. The right and the responsibility are yours."

"Nothing could more greatly damage our cause than if wo and our allies were to believe that peace has already been achicved and that our strength and unity were no longer required. But now for the first time in many years the path of peace may be open. No one can be certain what the future will bring. No one can say whether the time has come for an easing of the struggle, but history and our own conscience will judge us harshly if we do not now make every effort to test our hopes by action, and this is the place to begin." 